\title{
試験片の表面仕上程度が回転曲げ 疲労強度に及ぼす影響*
}

\author{
河本 実** 西岡邦夫***乾莘人****土谷富上雄****
}

\section{The Influence of Surface Roughness of Specimens on Fatigue}

\author{
Strength under Rotating-beam Test
}

\section{by Minoru Kawamoto, Kunio Nishioka, Tadahito InUi and Fujio Tsuchiya}

It has been well known, in general, that surface roughness of specimens gives comparatively noticeable effect on the endurance limit under rotating-beam test, and then that serious attention must specially be attracted for hard materials, sensible to the notch, when surface finishing is carried out.

No clear conclusions, however, have been quantitatively proposed with the relation between the roughness of surface and endurance limit, because the reason is, to begin with, intricate and difficult to analyze.

This study was commenced to clarify such relation, and the relations were obtained for the two kinds of carbon steels-medium and hard-by defining clearly the surface roughness.

While, we suggested a conception how consideration to the fatigue strength have to be done when subjected to a non-uniform stess distribution, such as in this example, with very small range. The conception is based upon the following two considerations: one is an expression of the non-uniform stress distribution, near the root of very minute and numerous scratches, with a probability density function, and another is to take into account the local plastic deformation near the root under the reversed stress. And, from that, satisfactory interpretation could be made to experimental results above-mentioned.

\section{1. 緒言}

試験片の表面仕上の程度により酎久限度が異なると とは古くから知られている.したがつて度労試験を実 施するにあたつては，なるべくよい仕上面の試験片を 作り，仕上げの影響を除去するよら努力が行われてい る。しかし鏡面に近いような仕上面を得るととは, 実 際問題として非常に手数がかかり, また, それほどま でしなくても，ある程度以上よい仕上面であれば，そ の影響は卮とんどないものを一般に考えられている。 そして研究者により，それぞれ自己が必要と思う程度 の仕上をしているのが現状のようである。

しかして，仕上面の粗さが耐久限度に影響を及ぼす とららことは, 主として仕上の時てでをる無数の小さ な傷功，切火としての作用をするためであると考えら れる. 切欠効果は, 従来よりよく知られているように, 材料の性質により異なるものである.したがつて仕上

\footnotetext{
* 原稿受付 昭和29年9月39日

** 正員 京都大学

*** 正員 発表当時京都大学

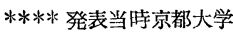

の場合にも同様なととが考えられるはずで, 粘々材料 では比較的粗い仕上面であつても，その影響は少ない かも知れない。乙狆反反て, 硬い材料では非常によ い仕上面の試験片を用いないと，かかる影響のほとん に除かれそ状態の試験はでをないであろら。したがつ て材料の種類によつても仕上粗さを変える必要がある わけである。

しかるに従来のとの種の研究では, とかく仕上粗さ の表示法が不朋瞭子ものが多く, 単に研削仕上とか旋 削仕上などの漠然とした言葉で表わしている。そし て, それらの仕上面亡耐久限度との関係を求めている。

上記のように仕上痕の切欠効果加問題になるという 考えからすれば，かよらな漠然とした仕上稆度の表示 では不充分で，なるべく定量的に表示しなければなら ない、まを仕上をする時には, 加工硬化の影響も含ま れる和それのあるととを注意せねばならない.最近 Tarasow \& Grover は仕上痕老試験片の軸方向以つ けて回転曲げ試験を行い, 仕上痕の切欠効果を除いて, 加工硬化の影響を調べている。また Fluck は種々の 
仕上粗さを root mean square で定量的に表わして, それらの粗さの試験片を数多く用いて, 同一試験忘力 に扣ける破壊までの繰返数のちらばりを求めている。 乙かし前者では, あまり加工硬化の程度の表示が明瞭 でなく，後者では仕上粗さが実験值のちらばりに文ば す影響はなんら特別な傾向がいよらである。しかし 最近の研究は次第に仕上粗さの定量的表示を行い，あ わせて加工硬化の影響も考慮に入れるようになつてい る.しかし仕上粗さと耐久限度との関係については, 後述するThomas の研究があるが，まだ明らかにされ たとは言えない。そして通常の疲労試験片の仕上程度 をどのくらいにすればよいかもはつきり解つていない. 本研究はかかる点在少しでも明らかとしようとして 行つたもので, 仕上程度を種々に変えるには, 粒度の 異なる研削低石，えめり紙，あるいはバフを用いた。 そして，かような方法で得られた種々の仕上程度の試 験片の回転曲げ耐久限度を求めて，任上粗さの影響を 明らかにした。な和材料によるとの影響の差異を知る そめに，一般的傾向を知るには不充分であるが，半硬 鋼と硬鋼の 2 種類の炭素鋼を用々た。

しかして，かような仕上粗さの影響は，前述のよう に仕上痕の切欠效果によるものであることは当然考え られる。Thomasは 1923 年に，とのような考えから 仕上粗さ乞耐久限度との関係を推定している。彼はま す仕上痕に似通つた単独の切欠につを実験して，その 切久の鋭さによる耐久限度の低下の程度を求めた。 そ して次に, 実際に種々の仕上面を作り，仕上痕の大を さをゼチン膜から求め, この中で最も鋭い仕上痕が 単独にあるものと考元, 上記の実験結果と比較して, 耐久限度の低下率を求めている。応力集中几対する理 論的研究がまだあまりなされていなかつた当時として は, 多重切欠の概念もまだあり知られていない。し たがつて最も鋭々仕上痕を 1 個だけ取り出し, それを 単独切欠と考えているが，とのよらな考えは現在では とのまま受け入れられない。しかし非常に昔にとのよ うな企てがなされたととは興味のあるととである。た だ Thomas はこのような推測により得られた結果に 対する実験を行つていないので, 実際に正しいかどう かは疑問である。
さて Thomas 以後には, 定量的な考察は見当らな ロようで,まを現在のところでは，任上痕を多重切欠 と考えると，その応力集中を簡単に知るとともでをな ロ.しかがつて仕上痕在そのまま取り出して, ある敛 さの切久と考えるととによる定量的考察は因難なよう 飞思われる。

そとで著者らは, 表面の軸方向に沿つての応力分布 を頻度函数により表わし, 繰返応力による材料の局部 的な塑性変形を考慮风大れるといら考えから耐久限度 を論じた. そして，乙の考えより導かれる仕上粗さと 曲げ耐久限度との関係は, 実験結果の説明飞有用であ るととが解つた。 な扣，乙の考えはより一般化すれ ば, 非常に狭以籁国で不均一な応力分有を生じている 場合の耐久限度を論じる一つの方法ではないかと思 5.

\section{2. 試験材料および試験片}

本試験に使用した材料は半硬鋼就よび硬鋼の 2 種類 で，その化学成分版よと機械的性質を Tables 1 およ び2に示した。

Table 1. Chemical Composition of Materials (\%).

\begin{tabular}{c|c|c|c|c|c}
\hline Mark & C & Si & Mn & P & S \\
\hline 3111 & 0.41 & 0.32 & 0.48 & 0.040 & - \\
2245 & 0.61 & 0.25 & 0.61 & 0.044 & 0.026 \\
\hline
\end{tabular}

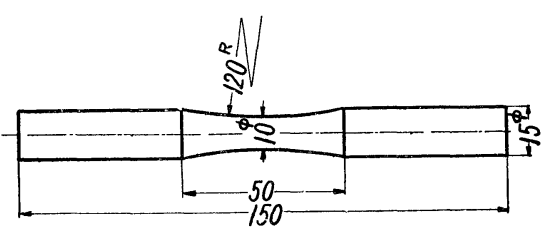

Fig. 1. Form of Specimen.

試験片は Fig. 1 亿示す形状のもので，この形《製作 した後, それぞれ Table 2 亿示したような熱処理を施 した。したがつて最初の旋削加工の影響は除去されて レると考えられる.とのよらにして作つた試験片に, 研削坁石, えめり紙, 和よびバフを有いて, 種々の仕 上を行つ方。

研削任上に用いた砥石はカーボランダムのヴィトリ

Table 2. Mechanical Properties of Materials.

\begin{tabular}{|c|c|c|c|c|c|c|c|}
\hline Mark & Heat Treatment & $\begin{array}{l}\text { Yield } \\
\text { Point } \\
\mathrm{kg} / \mathrm{mm}^{2}\end{array}$ & $\begin{array}{l}\text { Tensile } \\
\text { Strength } \\
\mathrm{kg} / \mathrm{mm}^{2}\end{array}$ & $\begin{array}{l}\text { Breaking } \\
\text { Strength } \\
\text { on Final } \\
\text { Area } \\
\mathrm{kg} / \mathrm{mm}^{2}\end{array}$ & $\begin{array}{c}\text { Elongation } \\
\%\end{array}$ & $\begin{array}{c}\text { Reduction } \\
\text { of Area } \\
\%\end{array}$ & $\begin{array}{c}\text { Hardness } \\
\text { Shore }\end{array}$ \\
\hline 3111 & $\begin{array}{l}\text { Heated at } 835^{\circ} \mathrm{C} \text { for } 30 \mathrm{~min} \text {. in } \\
\text { vacuum, then cooled in furnace. }\end{array}$ & $31 \cdot 8$ & $57 \cdot 5$ & 735 & $33 \cdot 0$ & $46 \cdot 7$ & $21 \cdot 8$ \\
\hline 2245 & $\begin{array}{l}\text { Heated at } 805^{\circ} \mathrm{C} \text { for } 30 \mathrm{~min} \text {. in } \\
\text { vacuum, then cooled in furnace. }\end{array}$ & 300 & $63 \cdot 7$ & $85 \cdot 6$ & $22 \cdot 3$ & $29 \cdot 6$ & $23 \cdot 3$ \\
\hline
\end{tabular}


ファイド硬度L のもので， $200 ， \$ 120$ ， \#46, および ‡36.の4 種類の粒度のものである. そして，これらの。 砥石はその研削面を半径 $120 \mathrm{~mm}$ の山面以成形し, 試 験片の軸に対して垂值方向の切込のみを与えて, 試験 片の中央部約 $25 \mathrm{~mm}$ の幅を仕上げそ. 尔和, 乙の場 合冷却剂は用的なつたが，切込量を非常飞少なくし て発熱を極度に抑え，加工硬化などの影響を除くよう 江注意した。な扣研削条件は，砥石周速度が約 1380 $\mathrm{m} / \mathrm{min}$ で, 試験片中央部の周速度は約 $110 \mathrm{~m} / \mathrm{min}$ で あつそ・

えめり紙仕上の時には， 120 ，\#， \#000の各えめり 紙を順次にかけ，最後汇 0000 をは で仕上げた。

バフ仕上は ら, 試験片の中央部 $25 \mathrm{~mm}$ の幅をベンガラを研㮌剎 として仕上した。

な㧊，えめり紙仕上执よびバフ仕上のいずれの場合 にも, 任上痕は試験片の軸に対して直角に, すなわち 円周方向にのみつくようにした。このような注意を払 づのは, 本研究の目的方侀削展汇よる切欠効果を知 るととに主眼を置いたからである。

本試験は小野式回転曲げ試験機を用いて行つたもの で，毎分回転数は約 1780 である.

\section{3. 仕上面の粗さの測定および表示法}

仕上面粗さの測定法には種々あるが, 本試験では触 針式検查機によつた。用らたのは小坂式仕上面検查機 で, これにより得られた仕上面の山凹より，JIS そ準 拠した方法で粗さを表示するととにした。

すねわち，オッシロ紙上に得られそ試験片の軸方向 の仕上面の山凸を, ウネリ曲線の影響を除くために, まず, その山山の一山尔いし二山が大る程度の間隔で 分割し, 次にその各間隔内に含まれる屾几の最大值を 求めた。そして1枚のオッシロ紙全体にわたつて求め られそととろの, このよらな山凸の中で, 並はすれた 大をな值を除を, 残りの中の最大值をその仕上面の粗 さとした。

さて，とのような粗さの表示法をとると，たとえ研 削条件が同一であつても, 同じ粗さの仕上面得ると とは非常に材難で,その粗さは相当大き学撒りを示す. したがつて，1つの $S-N$ 曲線を引くのに多くの試験 片を要するが, 粗さを何 $\mu$ と指定して, その粗さのも ののみを多く作るととができない。そとで，それぞれ の粗さそ応じそある範国の粗さのものは, その中間の 粗さで表示して, 同一のグループのものと考えて使用 するととにした。

らま, との粗さの範囲の分類を示したのが Table 3 で，この表にはそれらの箽网を代表さして考える粗さ 就よ゙それぞれの粗さのものを得を時の仕上条件を併
Table 3. Classification of Range of Roughness and the Finishing Condition.

\begin{tabular}{|c|c|c|c|}
\hline $\begin{array}{c}\text { Notation } \\
\text { of } \\
\text { Roughness }\end{array}$ & $\begin{array}{c}\text { Range } \\
\text { of } \\
\text { Roughness } \\
\mu .\end{array}$ & $\begin{array}{c}\text { Roughness } \\
\mu .\end{array}$ & Finishing Condition \\
\hline A & $0 \cdot 1 \sim 0 \cdot 2$ & $0 \cdot 15$ & $\begin{array}{l}\text { Polished with } 0000 \\
\text { Emery Paper }\end{array}$ \\
\hline $\mathrm{B}$ & $0.2 \sim 0.4$ & 0.3 & Buffed with Red Ocher \\
\hline $\mathrm{C}$ & $1 \sim 2$ & $1 \cdot 5$ & $\begin{array}{l}\text { Polished with } 0 \text { Emery } \\
\text { Paper }\end{array}$ \\
\hline $\mathrm{D}$ & $2 \sim 4$ & $3 \cdot 0$ & Grinded with $\sharp 200$, \\
\hline $\mathbf{E}$ & $4 \sim 10$ & $7 \cdot 0$ & $\int \# 120$ or $\# 16$ Grindstone \\
\hline $\mathrm{F}$ & $10 \sim 20$ & $15 \cdot 0$ & $\begin{array}{l}\text { Grinded with } \# 30 \\
\text { Grindstone }\end{array}$ \\
\hline
\end{tabular}

記した。 との表よりわかるように, 大体同一研磨条件

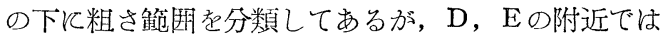

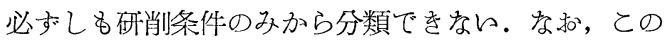
よらな分類をした場合のオッシロ紙上にさられた仕上 面を Fig. 2 亿示した.
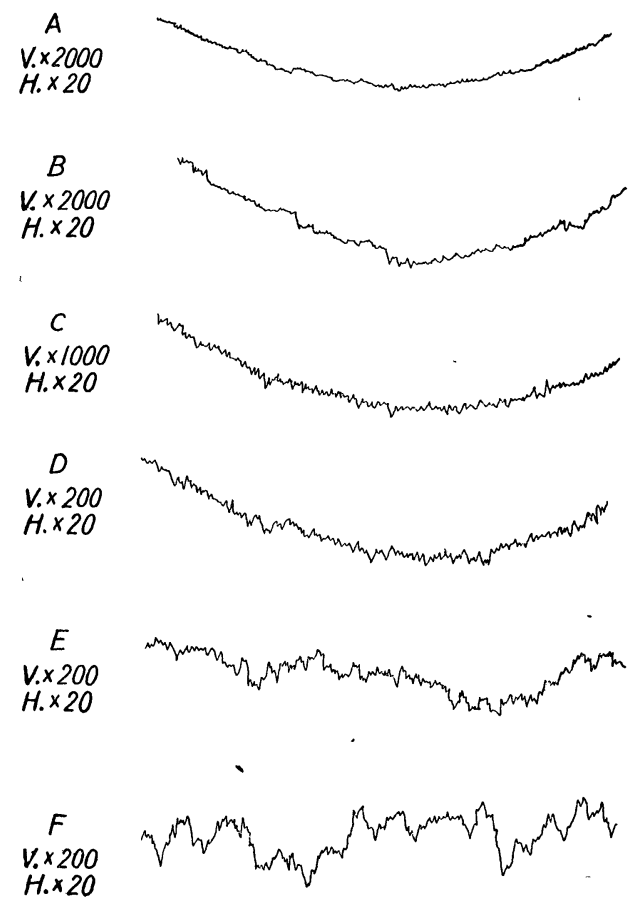

\section{V.: Vertical Magnification, H.: Horizontal Magnification}

Fig. 2. Profilograph of Finished Surface.

\section{4. 試 験 結 果}

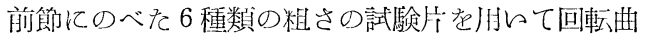

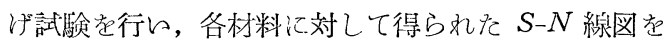
Figs. 3 扣よび 4 亿示した。 な祘, 乙れらのS-N線図 の傾斜部分は各粗さごとに破断したすべての試験片に つき最小自乗法を用的て求めた。亦耐久限度として は, 粗さがある笽困存もつているので最も適当と思わ れる值を採肞した。 


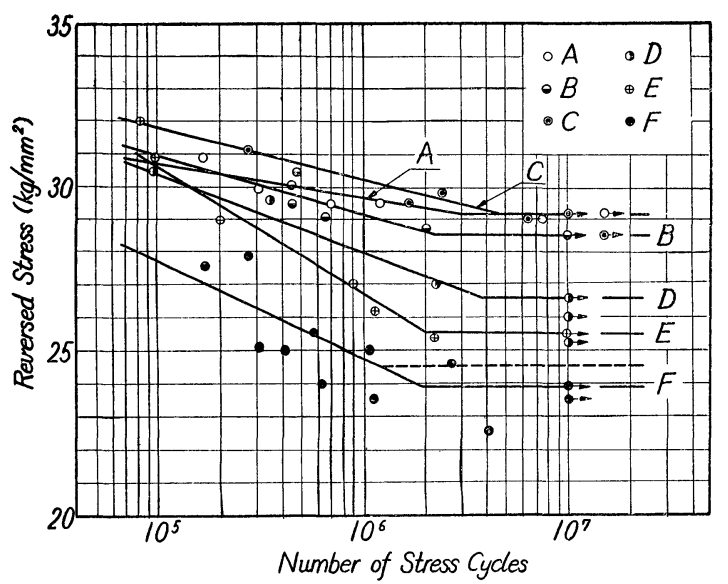

Fig. 3. $S-N$ Diagram (3111).

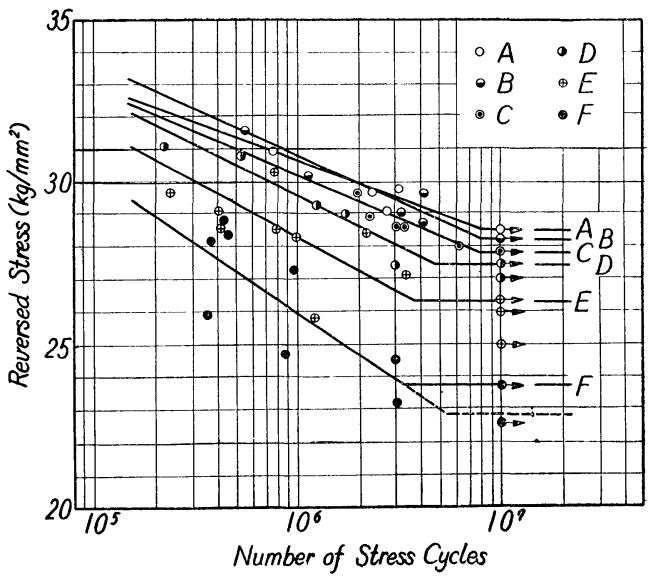

Fig. 4. $S-N$ Diagram (2245).

この結果より組さと曲げ耐久限度との関係走した のが Tables 4 和よど5である. そして同表《は, 粗 さA の場合の耐久限度 $\sigma_{w A}$ 基にして考えた場合の 各粗さの試験片の㴬久限度 $\sigma_{w}$ の比を， $\sigma_{w A} / \sigma_{w}$ 执よ び $\sigma_{w} / \sigma_{w A}$ の両者につ々て示した. 前者の $\sigma_{w A} / \sigma_{w}$ は粗さAのもの基集に考えを時の各粗さの試験片の 切欠係数に相当するものである。また後者の $\sigma_{w} / \sigma_{w A}$ は仕上が粗くなるにつれて聇久限度の低下する割合を

Table 4. Relation between the Roughness and the Bending Endurance Limit (3111).

\begin{tabular}{|c|c|c|c|c|}
\hline $\begin{array}{c}\text { Notation } \\
\text { of } \\
\text { Roughness }\end{array}$ & $\begin{array}{c}\text { Roughness } \\
\text { j. }\end{array}$ & $\begin{array}{c}\text { Bending } \\
\text { Endurance } \\
\text { Limit } \\
\mathrm{kg} / \mathrm{mm}^{2} \\
\end{array}$ & $\sigma_{w A} / \sigma_{w}$ & $\sigma_{u} / \sigma_{w 1}$ \\
\hline A & 0.15 & 285 & 100 & 1.00 \\
\hline B & 0.3 & $28 \cdot 3$ & 101 & 099 \\
\hline C & 1.5 & $27 \cdot 8$ & $1 \cdot 02$ & 0.98 \\
\hline D & $3 \cdot 0$ & 275 & $1 \cdot 04$ & 0.97 \\
\hline $\mathrm{E}$ & 70 & $26 \cdot 4$ & 108 & 0.93 \\
\hline $\mathrm{F}$ & 150 & 237 & $1 \cdot 20$ & 0.83 \\
\hline
\end{tabular}

Table 5. Relation between the Roughness and the Bending Endurance Limit (2245).

\begin{tabular}{c|c|c|c|c}
\hline $\begin{array}{c}\text { Notation } \\
\text { of } \\
\text { Roughness }\end{array}$ & $\begin{array}{c}\text { Roughness } \\
y\end{array}$ & $\begin{array}{c}\text { Bending } \\
\text { Endurance } \\
\text { Limit } \\
\mathrm{kg} / \mathrm{mm}^{2}\end{array}$ & $\sigma_{w A} / \sigma_{w}$ & $\sigma_{u} / \sigma_{w A}$ \\
\hline A & 0.15 & 29.2 & 1.00 & 1.00 \\
B & 0.3 & 28.5 & 1.02 & 0.98 \\
C & 15 & 29.2 & 1.00 & 1.00 \\
D & 30 & 26.6 & 1.10 & 0.91 \\
E & 7.0 & 25.5 & 1.15 & 0.87 \\
F & 15.0 & 23.9 & 1.22 & 0.82 \\
\hline
\end{tabular}

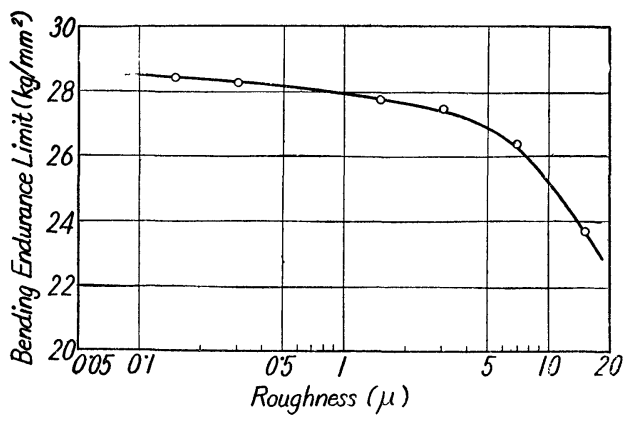

Fig. 5. Relation between the Bending' Endurance Limit and the Roughness (3111).

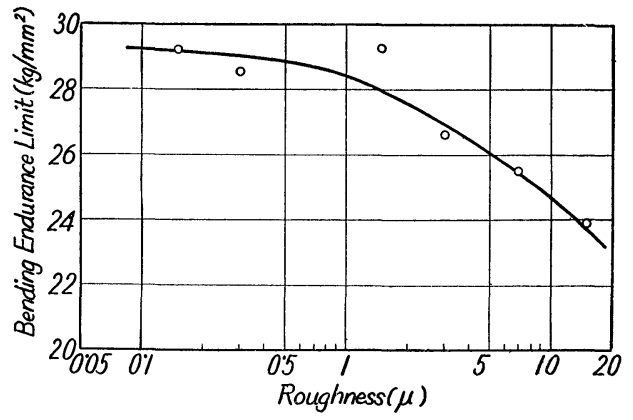

Fig. 6. Relation between the Bending Endurance Limit and the Roughness (2245).

示したものである。

らま曲げ耐久限度と粗さとの関係を各材料沉つき示 したのが Figs. 5 扣よび6である.とれらの図を見る と,粗さが小さら間は耐久限度の低下は僅少であるが, 大きくなると急激低下するととがわかる。そして， これらの図より，各材料て対して仕上粗さの影響をほ とんどなくするに必要な粗さは次のようになる。

材料 $3111 \cdots . . .$. 䄪 $3 \mu$ （虹200 研削彽石仕上）

材料 $2245 \cdots \cdots .$. 約 $1 \mu$ （\#元めり紙仕上）

すなわち，とれより硬い材料ほどよい仕上をせねば ならぬととも明らかである。

\section{5. 試験結果に対する考察}

緒言で述べたように，任上粗さにより附久限度が影 響走受けるのは，旋削や研削あるいはえめり紙仕上に 
より，表面にできる非常に小さ秝痕が切久としての 作用をするからである。そして任上が粗くなると，条 痕が荒くかつ梁くなり, 切欠効果が大きくなり, 耐久 限度が低下寸るものと考光られる。

したがつて，かかる条痕の切欠效果を明らがする ことがでをれば，仕上程度が耐久限度に及ばす影響を

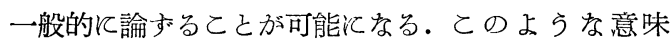
で Thomas の考皃な゙が提案されをものと思われる が，仕上痕は非常飞小さく,かつ接近しているために， 取扱いが林難で，理論的な応力集中の状態を知るとと 子不可能飞近r.

もし非常に近似的な応力集中率を推定し，乙れより

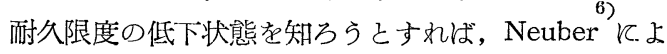
り解かれを多重切欠の式炕尖鋭切欠の概念を加味すれ

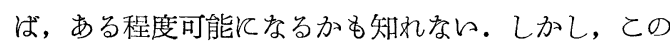
ような方法をとろらとすれば，条痕の形状の決定飞材

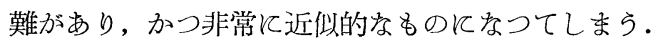

また最近よく問題にされているととろの, ある範囲 の応力の平均值飞より疲学破壊を論すると的ら方法か

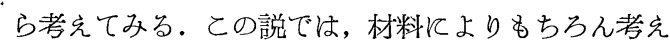

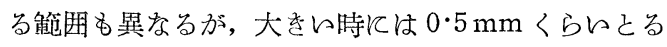
とともある。とのように大きい範囲を考光ると，との 中には任上痕が幾つも入つてきて, 平均した応力は粗 さの影響を受けなくなる。したがつて耐久限度の差異

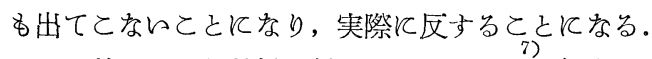

この外飞も町久效果に対する種々の考觉が提案され

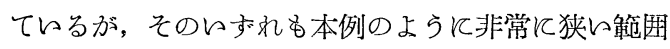
で, 不均一学応力状態が生じている場合の疲労強度の 問題を説明するには不充分のように思われる。 そこで 以下には，とのよう時の取扱的方法飞対する新し い考完を述べよう。

仕上面を掋大し てみると, Fig. 7 亿示すように非常 飞不均一学多くの 条痕からでをて和 $り$, 表面附近の応

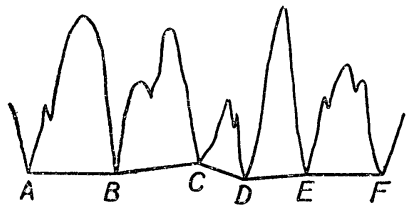

Fig. 7.
力は場所飞より非常飞異なつている。しかし痏学破壞 方起るのは, 同図で A, B , C , … F などで示した条 痕の底部あるいはその附近からであるう。そてで強度 上の考察を進めるには, これらの点を結てで線上ある 、はその近辺の応力分布状態を知る必要がある。

そとで，とのような仕上面をもつ試験片が静曲げモ ーメントを受けそ時に, 上記線上あるいは附近に生す。 る軸方向応力 $\sigma$ の分布飞つき考光る。乙れを弾性論か ら求めることは在とんぞ不可能なので, ここでは $\sigma の$ 分布が次のよう尔確辯密度函数 $f\left(\sigma / \sigma_{n}\right)$ で表わさ礼 るものと考光る。すなわち

$$
f\left(\frac{\sigma}{\sigma_{n}}\right)=m h\left(\frac{\sigma}{\sigma_{n}}\right)^{m-1} e^{-h\left(\sigma / \sigma_{n}\right)^{m}}
$$

ここに $\sigma_{n}$ は静曲げモーメントを断面係数で除して得 られる表面の見掛け応力である。 また $m$ 之 $h$ は度数曲 線の形を決める定数で, $m$ は尖鋭度を, $h$ は $f\left(\sigma / \sigma_{n}\right)$ の最大值の位置を決めるものである。

さて(1)で表わされる確率密度の平均值 $\sigma_{a} / \sigma_{n}$ は 次式で与えられる。

$$
\sigma_{a} / \sigma_{n}=\Gamma\left(1+\frac{1}{m}\right) / \frac{m}{h}
$$

しかして、らまのように条痕が連続して並んでロる時 には，、くつかの条痕を含ん任表面の軸方向飞和ける 線上の応力の平均值は，見掛讨応力 $\sigma_{n}$ 飞等しくなら ねばならない。すなわち

$$
\sigma_{a}=\sigma_{n}
$$

の関係が成立し，(2)より

$$
\sqrt[m]{h}=\Gamma\left(1+\frac{1}{m}\right) \text { まをは } h=\left\{\Gamma\left(1+\frac{1}{m}\right)\right\}^{m}
$$

となり，(1)式の与兊る応力分布の平均值が $\sigma_{n}$ 亿な るための $h$ 之 $m$ との関係が求められる。

したがつて(4)を(1)飞代大すると， $f\left(\frac{\sigma}{\sigma_{n}}\right)=m\left\{\Gamma\left(1+\frac{1}{m}\right)\right\}^{m}\left(\frac{\sigma}{\sigma_{n}}\right)^{m-1} \cdot e^{-\left\{\Gamma\left(1+\frac{1}{m}\right) \cdot\left(\sigma / \sigma_{n}\right)_{1}^{\prime m}\right.}$

となる。これで静曲げモーメントが作用した時の表面 に沿つての応力の分布をmの函数として表わすととが できた。

そして，乙の分布に和いて，ある応力 $\sigma$ よも大き 的㐫力の出る確率 $P\left(\sigma / \sigma_{n}\right)$ は

$P\left(\sigma / \sigma_{n}\right)=\int_{\sigma / \sigma_{n}}^{\infty} f\left(\frac{\sigma}{\sigma_{n}}\right) \cdot d\left(\frac{\sigma}{\sigma_{n}}\right)=e^{-\left\{\Gamma\left(1+\frac{1}{m}\right) \cdot\left(\sigma / \sigma_{n}\right)\right\}^{m}}$

より求められる.

以上で静曲げモーメントを受ける時の応力分布が明 らかとなつたので, 次疲労破壊が㞨る条件によ り支配されるかについて考えてみよう。すなわち換言 すると, 疲労試験開始時の応力分布が( 5 )式で示され る時には，らかなる条件の時が耐久限度になるかにつ らて考えてみる。

亲, そ の条件とし $\tau$, 上記の $P\left(\sigma / \sigma_{n}\right)$ がある值以 上飞なつた 時江疲労破 壊が起ると 考元る。 寸 なわち, (5) 式から求め

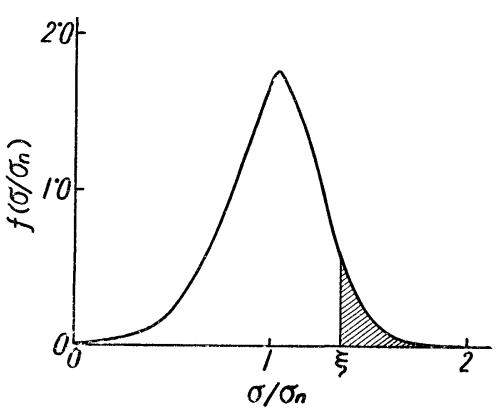

Fig. 8. 
られる分布曲線の形はFig. 8 亿示したようで，応力の 分布は 0 からめをでの間飞拡つている。しかし，との 分布は $\sigma_{n}$ なる見掛けの静曲げ応力を受けを時で， $\sigma_{n}$ が繰返曲げ応力として作用する時には，大きい応力の 部分は局部的飞塑性変形を生じて応力が低下し，その 附近の忘力はその低下を補つて増加する。そして全体 的㹸見ると，応力分布は次第化均一化されるものと考 光ら机る。的 Fig. 8 で, 斜線の部分の面積 $P\left(\sigma / \sigma_{n}\right)$ 飞相当する大きい応力の部分か均一化されて, 実際飞 試験片内《生じている応力は $\sigma^{\prime}\left(=\xi \sigma_{n}\right)$ より小さい応 力のみになつをとする。すると，との $\sigma^{\prime}$ が表面全 然切欠のない試験片（理想的な鏡面を有する試験片） の酎久限度 $\sigma_{w o}$ を超えな的限り疲労破壊しないわけ で，との $\sigma^{\prime}$ がちようぞ $\sigma_{w o}$ 亿等しくなる時の $\sigma_{n}$ が その仕上飞対与当耐人限度飞相当するととになる。

したがつて，西材料を用的て，西る粗さの仕上を 行つを時の耐久限度 $\sigma_{w}$ は, $m$ と $P\left(\sigma / \sigma_{n}\right)$ の值が知 られていると, 計算により求められる。すなわち( 6 ) 式にこれらの $\boldsymbol{m}_{\text {と }} P\left(\sigma / \sigma_{n}\right)$ の值を代入し $\tau \sigma / \sigma_{n}$ の 值を求めると，乙れが Tables 4 まをは 5 の 4 列目の 值飞相当する.

以上で考方方は明らかとなつをが，粗さを示すパラ メーターとしての $m$ 和よび $P\left(\sigma / \sigma_{n}\right)$ の值を実際の場 合にぞのように採るべきがついて次に考元る。

ます的くつて考光ると, この值は同一仕上粗さに 対しては,そと充材料が異なつても同じものでなけれ ばならない。そこで材料により耐久限度の低下率が異 なるというととは， $P\left(\sigma / \sigma_{n}\right)$ の值が材料により異な るととを意味している。すなわち比較的塑性変形しや すい材料では, 繰返応力による応力分布の均一化の程 度が大きいであろうというととは当然考えられるとと で，とのような材料では $P\left(\sigma / \sigma_{n}\right)$ の值は大きいわけ である。また，てれと反対に塑性変形しにくい材料で は, 応力分布の均一化が少なく, $P\left(\sigma / \sigma_{n}\right)$ の值も小 さらと考元られる. 換言すると, 同一の粗さでも, 材 料により耐久限度の低下率が異なるのは, それらの材 料が繰返空力を受ける時飞, 塑性変形を生じやすいか 否か，そして，その程度が大きいか否かによるもので あると考兊るわけである。

そとで実際に $m$ と $P\left(\sigma / \sigma_{n}\right)$ の值がモ゙のようとなる かにつき考えてみる. 本試験では 2 種類の材料に対し て, 粗さと耐久限度との関係を求めてある. したがつ て,それそれの材料注して適当な $P\left(\sigma / \sigma_{n}\right)$ を仮定 乙, 実験に上り得られた切欠保数几相当する $\sigma_{w A} / \sigma_{w}$

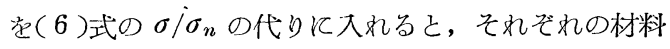
に対して, 各粗さの場合の $m$ の值が求められる。この よらにして各村料に対して求められを粗さと $m$ との関 係汸, 上記の考光が正しければ, 適当な $P\left(\sigma / \sigma_{n}\right) の$ 昭利 30 年 1 月
值を各材料に対して選えだ場合に一致せねばならない はずである。

らま材料 3111 和よび 2245 亿対して, $P\left(\sigma / \sigma_{n}\right)$ の

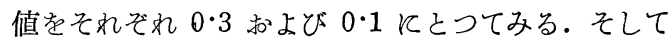
Tables 4 就よび 5 の $\sigma_{w A} / \sigma_{w}$ を用いて, 粗さと $m$ と の関係を各 材料に対し て求めたの が Fig. 9 で ある。同図 よりそれれ ぞれの材料 の粗さと $m$ との関係は よく一致し ているとと がわかる.

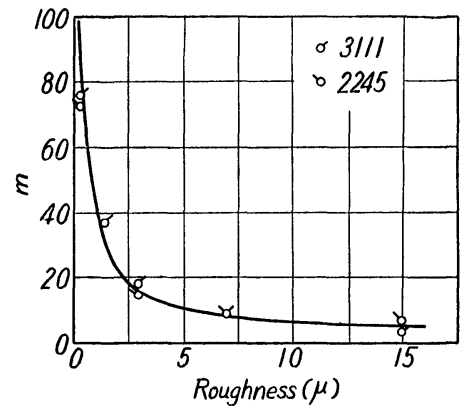

Fig. 9. Relation between $m$ and Roughness.
したがつて同図に示された粗さと $m$ との関係は, 仕上 面の応力分布を( 5 )式の確率密度函数で表わした場合

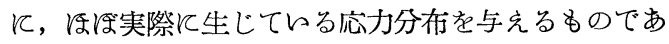
ろうと考允られる。

らまFig.9の実線で示した関係を用い,かつ $P\left(\sigma / \sigma_{n}\right)$ は上記の值をとつて, 各材料の粗さと $\sigma_{w} / \sigma_{w A}$ との 関係を計算してみると，Figs. 10 和よび 11 の実線の ようになる。この結果は, 当然のととであるが, 実験 值と注济一致している。をだ両材料とも粗さが $15 \mu$ 。

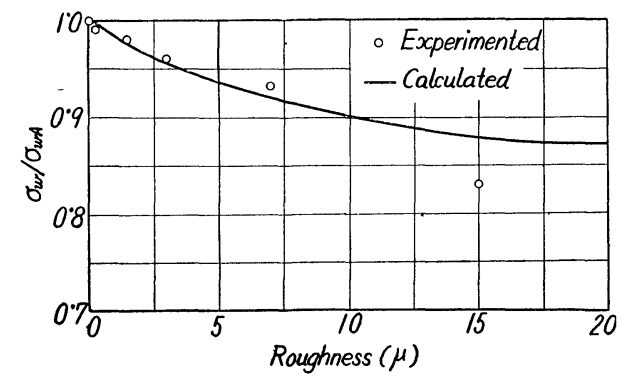

Fig, 10. Relation between Roughness and $\sigma_{w} / \sigma_{w A}$ (3111).

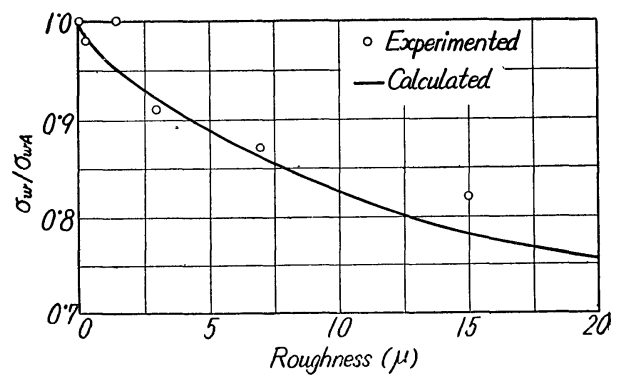

Fig. 11. Relation between Roughness and $\sigma_{w} / \sigma_{w A}(2245)$. 
の場合には, 計算值と実験值とが相当違つている。し かしとの差異は実験結果の方で耐久限度を決定する時 の困難さにも起因している。すねわち， いま計算值に 合うよう，反各材料の耐久限度を決めて，それを Figs. 3 和よび 4 の $S-N$ 線図上飞書きとむと，点線のように なる。乙れを実験值と考允合せて判断してみると，西 まり不合理な感じもしない。すなわち粗さが $15 \mu$ の 時は, 試験片個々の粗さ飞相当大きな撒りがあるため 飞, 耐久限度の決定飞困難があるぞで, 計算值が穾 験值とあまり一致しないのはとのそめであると思われ

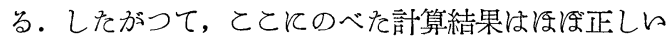
ものと考兊てよいであろう。

したがつて以上述べたよう取扱いは，仕上程度が 回転曲げ耐久限度に及深与影響を論するるの適して和 り，任意の材料がある粗さの仕上を受けそ時の附久限

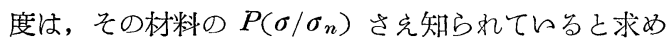
られる。方本実験で用いを 2 種類の材料から， $P\left(\sigma / \sigma_{n}\right)$ と $\sigma_{B}$ との関係を図示したのが Fig. 12 であ る.

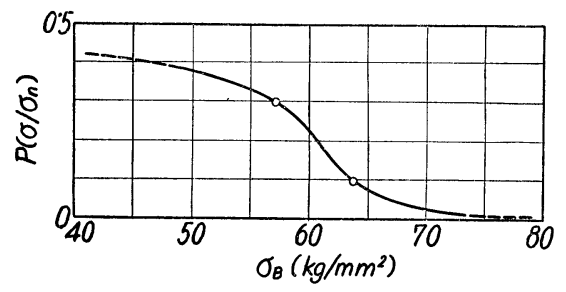

Fig. 12. Relation between $P\left(\sigma / \sigma_{n}\right)$ and $\sigma_{B}$

非常飞塑性変形による応力の均一化の行われやすい 材料季を゙ $P\left(\sigma_{/} / \sigma_{n}\right)$ は 0.5 そ近くなり，脆々ものでは
0 近づくわケである.

6. 結

論

本研究により得られた結果を要約すれば次のようで ある。

1. 炭素含有量が 0.41 和よど $0.61 \% の 2$ 種類の炭

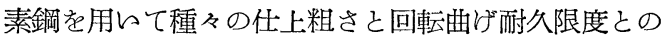
関係を明らかにした。

2. 疲労試験では, 仕上粗さの影響が质とんぞない 程度の試験片を用的必要にせまられるととが多い。 上記試験の結果, $0.41 \%$ 炭素鋼では粗さ約 $3 \mu$ （\#200 研削砥石仕上） $0.61 \%$ 炭素鋼では粗さ約 $1 \mu$ (\#0 杂 めり縒仕上）程度の仕上を行えば, この要求を満をさ れるととがわかつた。

3. 仕上面のように, 非常に狭的箐囲で不均一な応 力分布を生じている場合の, 疲労破壤飞対する一つの 考穴提案した。これ格各仕上条痕底附近の応力分布 を確率密度函数で与兄, 繰返応力に上る条痕底部附近 の局部的塑性変形を考虑飞入れをもので，上記実臨結 果に対する満足な説明を与学るととができた。

\section{洼: 一}

1) H.F. Moore, J.B. Kommers, Univ. Illinois Eng. Exp. Sta. Bull., 124, p. 178 (1921)

学振金属材料, I. 沁力論, p. 375 383 (炤和13年)

2) L.P. Tarasow, H.J. Grover, Am. Soc. Test. Mat., Proc., Vol. 50, p. 658 (1950)

3) P.G. Fluck, Am. Soc. Test. Mat., Proc., Vol. 51, p. 584 (1951)

4) W.N. Thomas, Engg., Vol. 116, p. 449 , p. 483 (1923)

5) JIS B 0601

6) H. Neuber, Kerbspannungslehre, Julius Springer (1937)

7) C.S. Yen, T.J. Dolan, Univ. Illinois Eng. Exp. Sta. Bull., 398 (1952) 